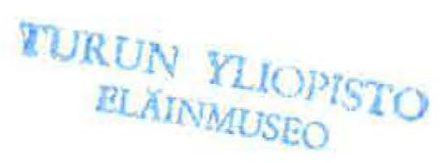

\title{
Proceedings of the XXIII Nordic Meeting of Entomology
}

The XXIII Nordic Meeting of Entomology was held in Turku, Finland, on 24-27 July 1994. The participants who gave a presentation in the meeting were informed that they could publish papers based on these presentations in a special issue of Entomologica Fennica. This is the issue which includes the papers submitted and accepted within the allowed time. As these articles are based on the meeting presentations, the dates of receipt and acceptance of the manuscripts are not given (i.e. the dates of "publication" are, in fact, the meeting presentation dates). Also, the lay-out and the contents of the articles do not necessarily comply with the usual standards of the journal.

In general, the articles have been arranged in alphabetical order by the authors. However, the article by Pekkarinen \& Huldén is placed as the first one because it fits naturally as a continuation of the excursion report to Karelia.

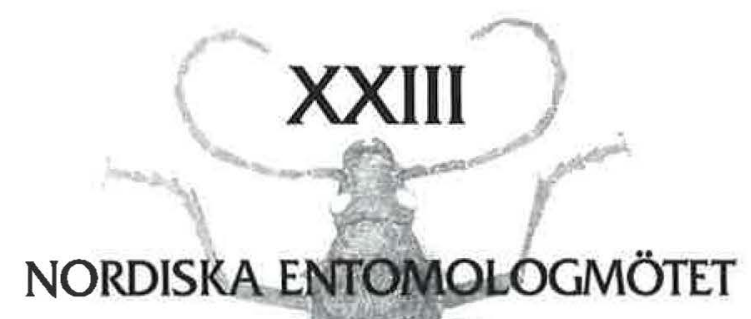

Zoologiska avdelningen och Zoologiska museet vid Ábo universitet 


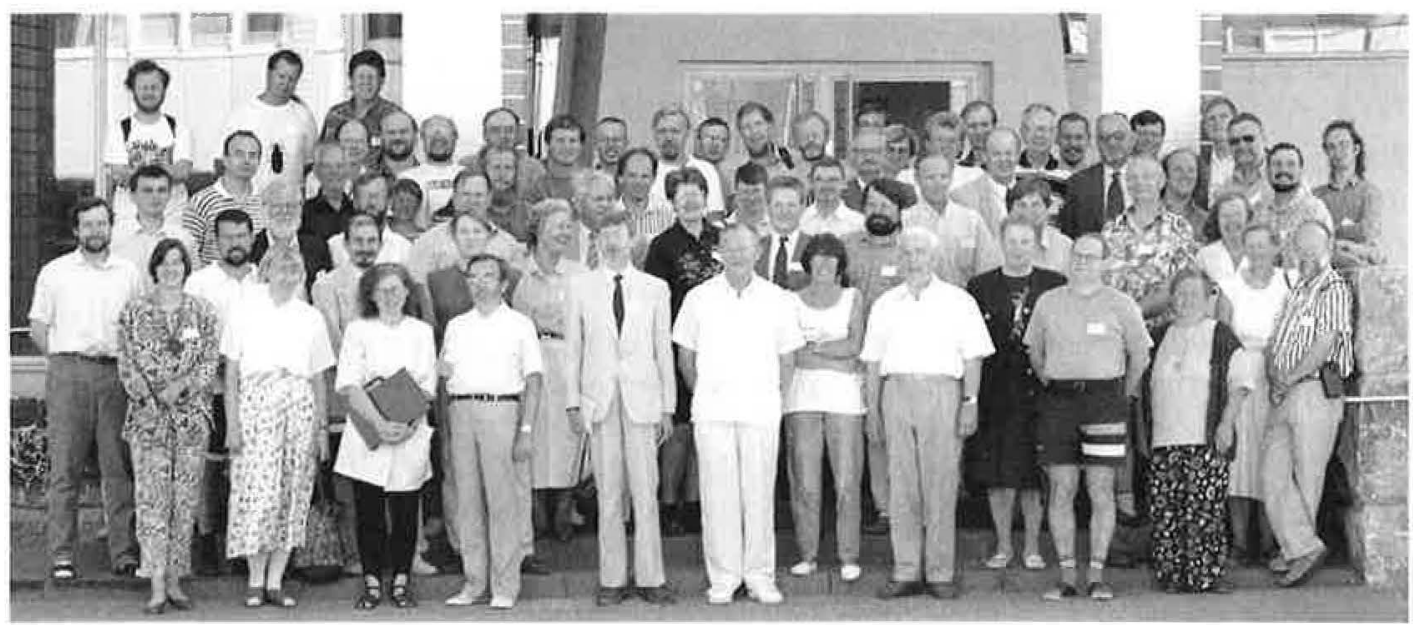

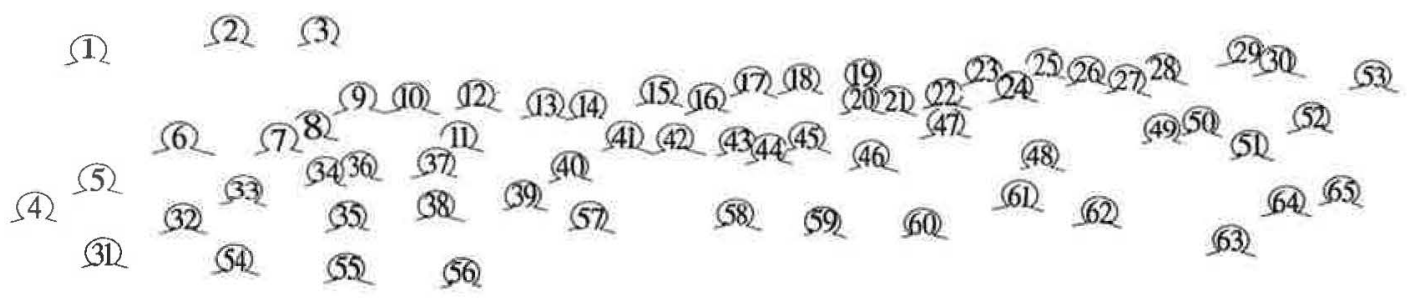

1. Larry Huldén, 2. Roger Petterson, 3. Björn Cederberg, 4. Veikko Rinne, 5. Tõnu Talvi, 6. Mikael Sörensson, 7. Carl-Cedric Coulianos, 8. Matti Viitasaari, 9. Bert Viklund, 10. Kauri Mikkola, 11. Juhani Itämies, 12. Sakari Kerppola, 13. Nils Hydén, 14. Seppo Pöykkö, 15. Olof Biström, 16. Marko Mutanen, 17. Göran Andersson, 18. Erling Ólafsson, 19. Martin von Numers, 20. Antti Pekkarinen, 21. Ulla Andersson, 22. Juhani Hynynen, 23. Andrej Humala, 24. Pekka Nuorteva, 25. Bertil Andrén, 26. Janne Kotiaho, 27. Jean-François Voisin, 28. Jari Niemelä, 29. Erkki Haukioja, 30. Pekka Lehtinen, 31. Minna Brown, 32. Lars-Ove Wikars, 33. Michael Saaristo, 34. Mati Martin, 35. Ilkka Teräs, 36. Kerstin Coulianos, 37. Ilpo Mannerkoski, 38. Anssi Junnila, 39. Pirkko Iivarinen, 40. Risto Iivarinen, 41. Bengt Weidow, 42. Gullvy Jonsson, 43. Elisabeth Hagström, 44. Sten Jonsson, 45. Torkel Hagström, 46. Seppo Koponen, 47. Pauli Bagge, 48. Jukka Salmi, 49. Ingvar Svensson, 50. Anders Albrecht, 51. Berith Långström, 52. Bo Långström, 53. Tarmo Virtanen, 54. Gunilla Ståhls, 55. Ritva Niemi, 56. Hans Silfverberg, 57. Niels Kristensen, 58. Ole Heie, 59. Arja Itämies, 60. Osmo Heikinheimo, 61. Sirkka-Liisa Nuorteva, 62. Ola Atlegrim, 63. Elsa Svensson, 64. Barbro Falk, 65. Thomas Falk. - Participants not at present at the time of photographing: Antti Aalto, Johan Andersen, Christer Jönsson, Kari Karhu, Pekka Käär, Esa Lehikoinen, Irene Routio, Boel and Joar Mårtensson, and Simo Veistola. 


\section{The XXIII Nordic Meeting of Entomology in Turku 24-27 July and the excursion to Ladoga and Olonets Karelia (Russia) 28 July-1 August 1994}

The Nordic Meeting of Entomology has been held six times in Finland, for the first time in 1930, and now it has taken place for the first time outside Helsinki. The Entomological Society of Finland, together with the Zoological Museum and the Laboratory of Ecology and Animal Systematics of the University of Turku, were the organizers of this meeting. The organization was financially supported by the Ministry of Education of Finland, the Turku University Foundation, the University of Turku, the City of Turku and the Environmental Protection Office of Turku. The contributions of these supporters as well as the great work of many private persons on behalf of the meeting are most gratefully acknowledged. A total of 73 persons were registered as participants of the meeting. Two of the participants were from Denmark, one from Norway, 26 from Sweden, one from Iceland, two from Estonia, one from Russia, one from France and 39 from Finland. All sessions were held at the Arcanum House of the University of Turku. Mrs Minna Brown served as the secretary and Mr Risto Iivarinen as the treasurer of the meeting.

The participants convened on Sunday, 24 July, to an unofficial evening party. The meeting was opened on Monday, 25 July, by Dr. Antti Pekkarinen, the chairman of the Entomological Society of Finland and stated (in Swedish):

"Här i Åbo befinner vi oss vid rötterna av Finlands civiliserade kultur. Finlands första universitet grundades ju här 1640. Samtidigt befinner vi oss också vid den finländska entomologins rötter. Den första egentliga finländska entomologen var Linnés samtida Isaac Uddman, som studerade vid Åbo universitet. Han flydde sedermera till Uppsala, där han blev Linnés elev. Den mesta berömda finländska naturforskaren under 1700-talet, Pehr Kalm, verkade här som professor under Linnés tid och också han hade entomologiska intressen. Den berömde coleopterologen Carl Reinhold Sahlberg, den första $\mathbf{i}$ den fyra generationer långa Sahlbergska entomologdynastin, verkade här som professor i början av 1800-talet.

Åbo brand 1827 betydde en stor katastrof, då största delen av Åbo totalförstördes och hela universitetet med samlingarna och biblioteket brann upp. Sahlbergs skalbaggssamling lyckade man dock rädda och hans insektskåp och samlingar är numera i Åbo universitets zoologiska museum. Efter branden flyttades det gamla universitetet till Helsingfors. Dock för drygt 70 år sedan, snart efter att Finland hade vunnit självsständigheten, grundades tvă nya universitet i Åbo, finskspråkiga Turun Yliopisto och svenskspråkiga Åbo Akademi. Mycket livlig entomologisk och arachnologisk forskning har pågått här under det nya universitets tid."

Dr. Seppo Koponen from the University of Turku extended a welcome to the participants on behalf of the local organizers. Dr. Niels P. Kristensen, the chairman of the Entomological Society of Copenhagen, was elected as the President of the meeting and he conveyed greetings from his Society. Dr. Sten Jonsson presented regards from the Entomological Society of Sweden and Dr. Hans Silfverberg greetings from the Societas Entomologica Helsingforsiensis. The meeting decided to send telegrams of greetings to Dr. Astrid Löken (Oslo), Prof. Edward Sylvén (Stockholm), Dr. Leif Lyneborg (Copenhagen), Prof. Walter Hackman (Helsinki) and Prof. Harry Krogerus (Helsinki). The opening lecture was given by Prof. Erkki Haukioja.

The City of Turku had invited the participants to a party on the evening of 25 July. The Deputy Mayor, Mr. Armas Lahoniitty, extended a welcome to the meeting and the President of the meeting expressed thanks to the City. 
The lectures and posters presented and the sessions arranged were as follows (those marked with an asterisk are published in this issue of Entomologica Fennica):

\section{Opening session}

Erkki Haukioja: Research of insect herbivory at University of Turku

\section{Ecology and faunistics}

Chairmen Ingvar Svensson and Erling Olafsson

Johan Andersen: En sammenligning av fangster av carabider $\mathrm{i}$ kvadratprover og fallfeller *

Pauli Bagge: Emergence and upstream dispersal of adult lotic mayflies and caddisflies in a lake outlet (Central Finland) *

Ole E. Heie: A survey of the aphid fauna of Fennoscandia and Denmark (Homoptera, Aphidoidea) *

Janne Kotiaho: Smaller males do better in agonistic encounters of a drumming wolf spider Hygrolycosa rubrofasciata (Araneae, Lycosidae)

Jari Niemelä: Distribution of carabid beetles on islands in the Archipelago Sea, SW Finland

Hans Silfverberg: Expansion hos insekter i Finland *

Ilkka Teräs: Bumblebee visits to different colour morphs of Lupinus polyphyllus *

\section{Milieu protection and threatened insects}

Chairman Kauri Mikkola

Ola Atlegrim: Pattem in ground- and field-layer invertebrates following logging (Atlegrim \& Sjöberg)*

Bo Långström: Insect in burned forests - forest protection and faunal conservation (preliminary results) (Ehnström et al.)*

Pekka Nuorteva: Överförning av kadmium från myror till myrlejon *

Roger Petterson: Spindelfaunan i lavgranskog

Lars-Ove Wikars: Good dispersal capacity at the cost of reduced fecundity in the fire-adapted beetle Melanophila acuminata (Coleoptera: Buprestidae)

\section{Systematics and phylogeny}

\section{Chairman Olof Biström}

Niels P. Kristensen: Lepidoptera phylogeny - the state of art

Mikael Sörensson: On a supposed stridulatory device in Nanosella Motsch. - the world smallest beetles (Coleoptera, Ptiliidae)

\section{Entomology in Estonia, Iceland and Karelia}

Chairman Ole Heie

Tõnu Talvi: Nordic entomologists and Estonian fauna

Erling Olafsson: Entomology in Iceland

Antti Pekkarinen: Naturen i Ladoga och Olonets Karelen (Pekkarinen \& Huldén)*

\section{Posters}

Juhani Hynynen: Plecopteran communities and annual emergence in five forest streams and two lake outlet streams of Central Finland (Bagge \& Hynynen)*

Anssi Junnila: The sheep tick (Ixodes ricinus), the carrier of serious diseases in Finland

Seppo Koponen: Ground-living arthropods along pollution gradient in boreal pine forest, Finland *

Mati Martin: About the distribution of some pyralid moths in Estonia

Michael Saaristo: Distribution maps of outdoor myrmicid ants in Finland (Hymenoptera, Formicidae) with taxonomical and ecological notes *

Tõnu Talvi: Carabid beetle assemblages in a wooded meadow and on the adjacent habitats on the Saaremaa Island, Estonia *

Simo Veistola \& Esa Lehikoinen: The fluctuation in abundance of arthropods during summer at Kevo, northernmost Finland - a bird eye's view (Veistola et al.)*

Tarmo Virtanen: A comparison of the responses of Orthosia spp. (Lepidoptera, Noctuidae) with different distribution ranges to different temperatures and food plants

Lars-Ove Wikars: Ascomycete fungi and fireadapted insects; symbiotic relationship?

Kari Karhu: Hotade insekter på Runsala (Karhu et al.)* 


\section{Closing session}

\section{Chairman Niels P. Kristensen}

In the closing session on Wednesday, 27 July, the assembly discussed the possibility of founding a new Nordic journal for general entomology. For the present, Entomologica Fennica is the only international journal in the Nordic countries publishing in all fields of entomology. Especially in Sweden and Norway there is an obvious need for a journal of general entomology. A lively discussion also ensued about the future of Nordic meetings. The President noted the proposal of Danish entomologists to discontinue the Nordic meetings and their statement that they are not willing to organize the next meeting in Denmark. This decision was based mainly on the low number of participants in the last Nordic meetings and on the fact that there are nowadays so many other congresses, e.g. the quadrennial European Congress of Entomology. However, the meeting decided almost unanimously to continue the Nordic meetings, but expressed the desire to expand them to include also the Baltic countries. The Estonian participants expressed their great interest for organizing the next meeting in Estonia and the assembly agreed that the following meeting will be held in 1997 in Tartu.

The congress dinner and farewell party were held at the Samppalinna restaurant. The President of the meeting and several other persons gave speeches on this occasion.

\section{Excursions}

\subsection{Ruissalo}

On the evening of 25 July a short excursion was made to the largest oak forest of Finland on the Isle of Ruissalo in the vicinity of the City of Turku (organizer Kari Karhu). In connection with the meeting, Ole Heie, Osmo Heikinheimo and Anders Albrecht made unofficial excursions in southern Finland and collected almost one hundred species of Aphidoidea, of which at least two were new to Finland.

\subsection{Ladoga and Olonets (Aunus) Karelia}

After the first Nordic meeting in Finland, in 1930, an excursion was made to the Karelian Isthmus and to Ladoga Karelia (Terijoki, Sortavala and the Island of Valamo). Now, after 64 years, it was again possible to visit the areas of Ladoga Karelia which Finland lost after the war and which remained closed to non-Soviet people for more than 40 years.

The excursion was made by bus and headed by Risto livarinen and Antti Pekkarinen. The number of participants was 30 (20 from Sweden, one from Iceland, one from France, one from Russia and seven from Finland). The weather was excellent and warm during the whole excursion.

On Thursday, 28 July, a long trip (almost $700 \mathrm{~km}$ ) from Turku via Vyborg to Sortavala allowed short stops for collecting only in Muolaa ("the Mannerheim line") and about $10 \mathrm{~km}$ north of Käkisalmi. As the condition of the road from Käkisalmi to Sortavala was quite bad, the arrival in Sortavala was delayed until late in the evening.

On the next day, 29 July, a major collecting stop was made near Sortavala in Kirjavalahti on the shore of Lake Ladoga in a rich grassland and a grass-herb forest (rich with Aconitum septentrionale). The next stop was in Impilahti, again in a rich grassland near the river Sumeria with deep banks and later a short stop was made on a pine bog near Pitkäranta. The next stop was in Salmi near the ruins of the Orthodoxy church on a grassland and a riverside biotope. The last stop before Olonets was in Vitele on a fine and large sandy shore of Lake Ladoga.

29 July was the 75th anniversary of Ingvar Svensson, "The Grand Old Lepidopterologist of Sweden". During the evening meal in Olonets Sten Jonsson gave a speech in honour of Ingvar and donated to him a symbolic specimen of Ochsenheimeria.

On 30-31 July several collecting excursions were made in the Olonets area. During two nights the lepidopterologists collected on the banks of the River Olonka (Fig. 1) and in the village of Koukkula near the magnificent River Svir. In the daytime collections were made on various grassland and riverside biotopes near Olonets and Koukkula. On $31 \mathrm{July}$, most of excursionists visited a protected area of Nizhnie-Svirski and made collections in a fine primeval mixed forest rich with old aspens and lindens (Fig. 2). Transportation to the area was arranged (by tractor!) by the head of the Gumbaritza 

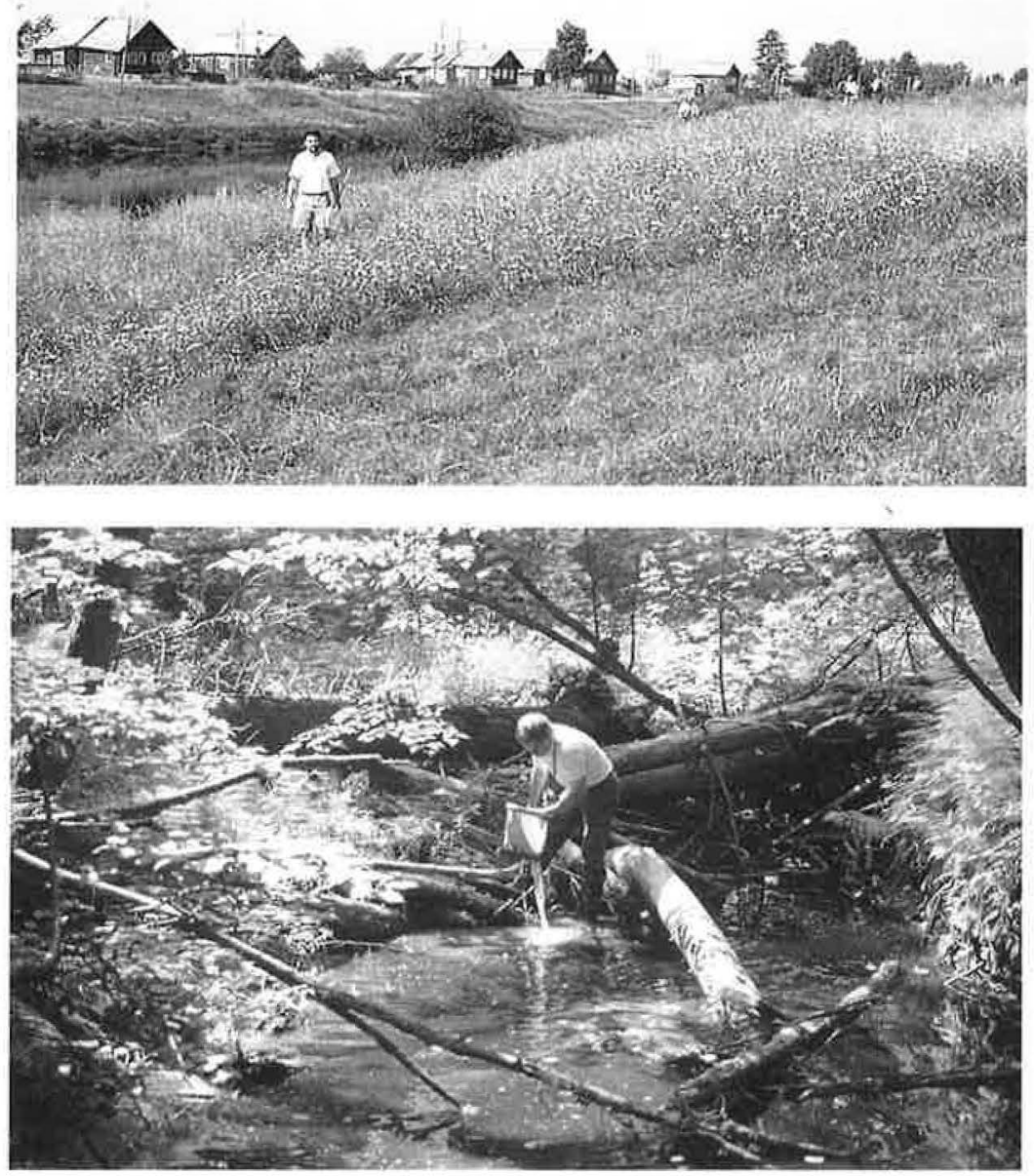

Fig 1. Grassland on the bank of the River Olonka in Olonets. Three Centaurea species including C. phrygia are very abundant here. (Photo: R. livarinen).

Fig. 2. Luxuriant grassherb primeval forest in the conservation area of Nizhnie-Svir in Gumbaritza, Olonets. Dominant trees are Tilia cordata, Acer platanoides, Populus tremula and (fallen trunks) Picea abies. (Photo: R. livarinen).
Ornithological station, Dr. Viktor Kovalev.

The visit in the magnificent former monastry of Svir was unforgettable, as was the return to Finland in the warm night between 31 July and 1 August around Lake Ladoga via St. Petersburg. During a short stop in the morning twilight on the bank of the River Neva near the St. Petersburg University, the excursionists could enjoy the exotic scene over "The Venice of the North".

The excursion and the meeting were generally regarded as successful and the organizers have been very glad for receiving so many letters of acknowledgement afterwards. Let us hope that we shall meet again in Estonia in 1997!

List of some interesting finds of insects during the excursion:

\section{Kirjavalahti 29.7.}

Coleoptera: Hydroporus acutangulus Thomson and Apion spencii Kirby; Heteroptera: Coptosoma scutellatum (Geoffroy).

\section{Salmi 29.7.}

Coleoptera: Amara equestris (Duftschmid), Ophonus puncticollis (Paykull), Eledona agricola (Herbst) and Pachenoporus pilosus (Rossi); Lepidoptra: Depressaria pimpinellae Zeller. 


\section{Vitele 29.7.}

Coleoptera: Hydrosmecta tenella (Mannerheim).

\section{Olonets 30-31.7.}

Coleoptera: Bembidion andreae polonicum J. Müller, $B$. semipunctatum (Donovan) Harpalus froelichii Sturm, Coelambus polonicus (Aubé), Hydroporus neglectus Schaum, H. longicornis J. Sahlberg, Hydaticus aruspex Clark, Ptiliolum caledonicum (Sharp), Ischnopoda coarctata (Erichson), Rhizophagus puncticollis Sahlberg, Cryptophagus lindbergorum Bruce, Hippodamia notata (Laicharting), Anoplodera livida (Fabricius), Apion laticeps Desbrochers des Loges, Rhynchaenus alni (Linnaeus); Lepidoptera: Ochsenheimeria urella Fischer von Röslerstamm, Semiothisa artesiaria (Denis \& Schiffermüller), Victrix umovii (Eversmann), Autographa excelsa (Kretschmar), Ipimompha contusa (Freyer); Heteroptera: Acetropis gimmerthalii (Flor) and Coranus aethiops Jakovlev; Diptera: Chrysops parallelogrammus Zeller.

\section{The organizing Committee}

Antti Pekkarinen, Larry Huldén, Risto Iivarinen, Seppo Koponen, Ilpo Mannerkoski, Ritva Niemi, Veikko Rinne and Ilkka Teräs 
. 